\title{
Monitoring of ear head worm Helicoverpa armigera (Hubner) through sex pheromone in pearl millet crop
}

\author{
R.P. JUNEJA, G.M. PARMAR*, Y.H. GHELANI ${ }^{1}$, K.D. MUNGRA², P.R. PATEL ${ }^{3}$ AND N.N. CHAUDHARI ${ }^{3}$ \\ Department of Entomology, Junagadh Agricultural University, JAMNAGAR (GUJARAT) INDIA \\ ${ }^{1}$ Director of Research, Junagadh Agricultural University, JUNAGADH (GUJARAT) INDIA \\ ${ }^{2}$ Department of Plant Breeding, Junagadh Agricultural University, JAMNAGAR (GUJARAT) INDIA \\ ${ }^{3}$ Department of Plant Physiology, Junagadh Agricultural University, JAMNAGAR (GUJARAT) INDIA
}

\section{ARITCLE INFO}

Received : 28.02 .2015

Revised : 26.07.2015

Accepted : 10.08 .2015

\section{KEY WORDS :}

Helicoverpa armigera, Pheromone traps, Moth catches, Larval counts, Correlation

*Corresponding author:

Email: dr_gmparmar@ rediffmail.com

\begin{abstract}
Monitoring of adults of ear head worm Helicoverpa armigera (Hubner) through male sex pheromones was studied during Kharif 2002 to 2011 in pearl millet crop at Jamnagar, Junagadh Agriculture University, Junagadh. Highest number of moth catches was recorded during $35^{\text {th }} \mathrm{MSW}$ i.e. $27^{\text {th }}$ August to $2^{\text {nd }}$ September. Adult moth catches were found negatively correlated with maximum temperature $(\mathrm{r}=-0.1698)$. Farmers are advised to install sex pheromone trap for monitoring and mass collection of adult male moth of $H$. armigera @ 5 traps/ha at a height of $2.0 \mathrm{~m}$ from $1^{\text {st }}$ week of August to $2^{\text {nd }}$ week of September.

How to view point the article : Juneja, R.P., Parmar, G.M., Ghelani, Y.H., Mungra, K.D., Patel, P.R. and Chaudhari, N.N. (2015). Monitoring of ear head worm Helicoverpa armigera (Hubner) through sex pheromone in pearl millet crop. Internat. J. Plant Protec., 8(2) : 245-249.
\end{abstract}

